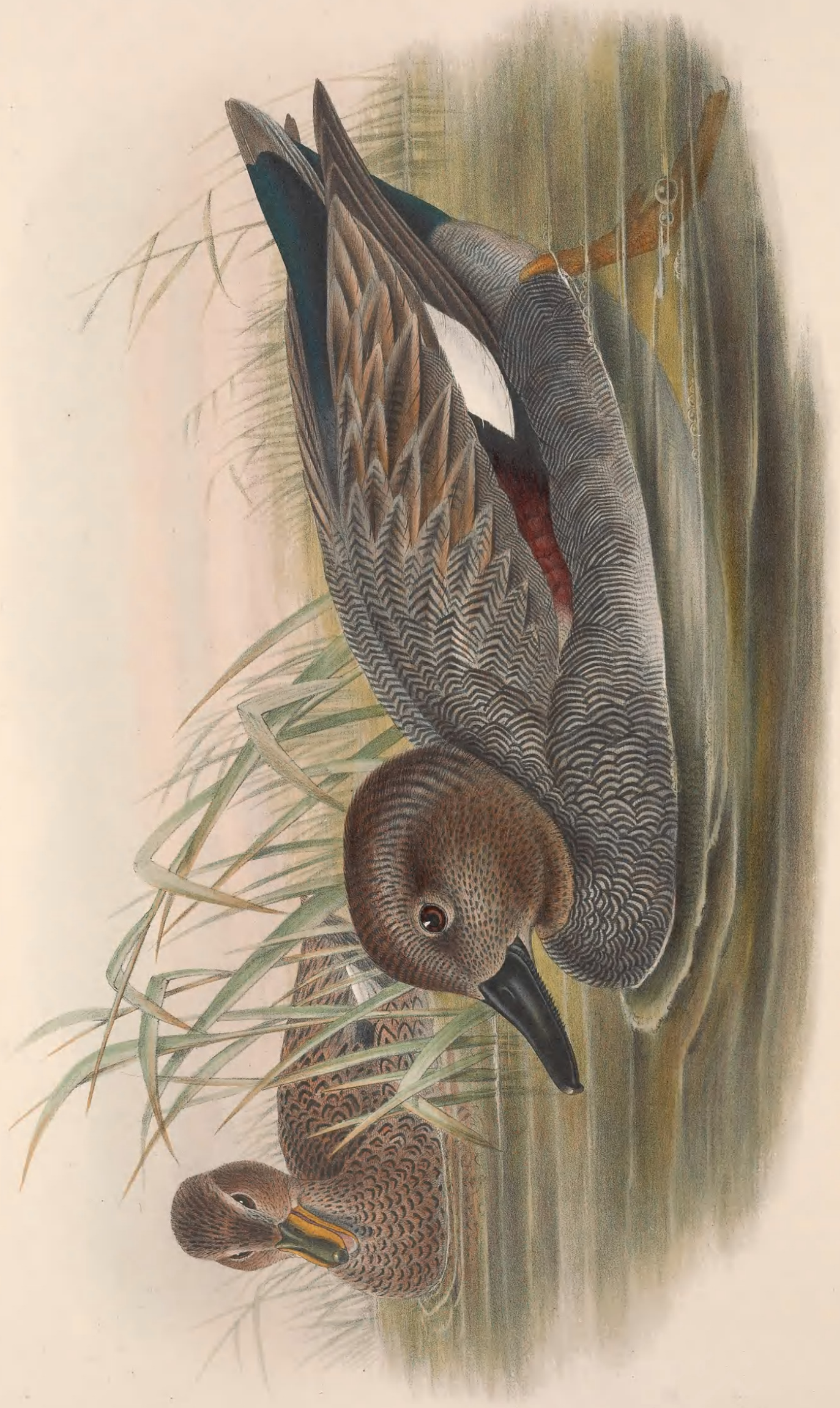

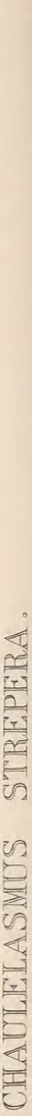

है 


\section{CHAULELASMUS STREPERA.}

\section{Gadwall.}

Anas strepera, Linn. Faun. Suec., p. 43.

- cinerea, Brehm, Vög. Deutsch,, p. 871.

Chauliodus strepera, Swains. Journ. Roy. Inst., vol, ii. p. 19

Ktinorhynchus strepera, Eyton, Monogr. Anat., p. 137.

Chaulelasmus strepera, G. R. Gray, List of Gen. of Birds, 1840, p. 74.

Querquedula strepera, Macgill. Man. Nat. Hist., Orn., vol. ii. p. 169.

I BELIEve it will be admitted that some species of our water-fowl are numerically much more abundant than others : thus the common Wild Duck is extremely plentiful in all the countries it inhabits; and the same may be said of the Teal; while the Shoveller and Tufted Duck, although common birds, are fewer in number, and somewhat less circumscribed in their habitat. The Gadwall is not numerous anywhere. In the British Islands, as in Europe generally, except, perhaps, in Holland, its appearance is uncertain, and its numbers never very great; indeed it mostly occurs either singly or iu pairs.

Leadenhall Market, the great emporium for water-fowl, is the best locality for the British collector to obtain specimens for his cabinet-a batch of aquatic birds from the decoys of Suffolk, Norfolk, and Lincolnshire frequently comprising a solitary Gadwall; and examples are often occurring in the great crates of Ducks sent from Holland. In the central and southern parts of the European continent it is about as common as in Holland, North Africa, Asia Minor, and India; in fact we may say that it inhabits the temperate regions of both the Old and the New World; for it is distributed over the whole of the northern portion of America, from the fur-countries to Florida, and in the Old World, from Europe to Japan.

"From Dr. Richardson's account," says Swainson, "it braves the rigours of the arctic regions, breeding in the wooded districts of the Barren Grounds, up to their most northern limits, in lat. $68^{\circ}$; and he shot specimens on the Saskatchewan, towards the middle of May.

"The haunts of the Gadwall, in America, are the lakes, rivers, and marshes of the interior, particularly such as abound with reeds and rank aquatic grasses, in which they so much delight as seldom to visit the sea-coast : their food of course is procured in such situations, and consists of aquatic insects, plants, and seeds. They feed during the night, and pass the day concealed amongst the weeds and rushes. In comparison with the Mallard and other kindred forıns, its powers of flight are very superior ; and, unlike most of the river-ducks, it dives with the same facility and frequency as many of the marine ducks."Anim. in Menag., p. 252.

Little or no imformation respecting the breeding-places of the Gadwall in the Old World has been recorded; and perhaps the only authentic eggs known are those laid by captive specimens in our menageries. The bird has bred repeatedly in the Gardens of the Zoological Society; and an egg "left unhatched," says Mr. Yarrell, was of a buffy white, tinged with green, and measured two inches and two lines in length, by one inch and eight lines in breadth. Mr. Hewitson, in the third edition of his 'Coloured Illustrations of the eggs of British Birds,' states that Mr. Proctor " found a single nest of the Gadwall in Iceland, placed near the edge of some fresh water, among reeds; it was composed of dry grass, and the eggs were five in number." But Mr. Alfred Newton is somewhat doubtful as to the bird's breeding in that country ; for in his ornithological notes to Mr. Sabine Baring Gould's 'Iceland, its Scenes and Sagas,' he says, "looking upon this as a bird of much more southern range, I have omitted its name from my list, but shall willingly own I am wrong, on receiving good testimony to the contrary."

Thompson says the Gadwall is of rare occurrence in Ireland, and enumerates only about twenty examples as having come to his knowledge in eighteen years, but adds that he had been informed by Mr. J. Watters, Jun., of Dublin, " that he has seen at least one on sale by wild-fowl dealers in the course of every winter for some years past, all of which had been killed in Ireland," and remarks " this singularly agrees with what is said of the Gadwall in the east of England; for the Rev. Mr. Lubbock informs us that it is scarce in Norfolk, but is generally seen in Norwich market once or twice in the winter."

Mr. Jerdon, in his recently published 'Birds of India,' informs us that the Gadwall is by no means a rare bird in any part of that country during the cold weather, that it generally frequents the more open and larger tanks in moderately large parties, that its flight is rapid, and its voice not unlike that of the common duck, and that it is justly considered one of the best wild ducks for the table. Temminck states that specimens from Japan do not differ in any respect from those found in Europe.

Structurally the Gadwall is a swimming and buoyant rather than a diving bird, its general contour being 
graceful, its bill small and narrow as compared with that of other ducks, its feet delicate, and its wings long and pointed. "The windpipe," Mr. Yarrell informs us, "is rather small in calibre, with a slight enlargement of the tube about two inches above the bony protuberance. The voice is lond; and hence it obtained the name of strepera." Its food, like that of the Common Duck, the Pintail, and the Teal, is said to consist of grasses and water-plants; its flesh is savoury and excellent.

That with proper care and attention this species might become semidomesticated seems likely. I have mentioned above an instance of its breeding in the Gardens of the Zoological Society; and Dr. Bachman, in a note to Audubon, says:- "In the year 1812 I saw in Duchess County, State of New York, at the house of a miller, a fine flock of Ducks, to the number of at least thirty, which from their peculiar appearance struck me as different from any I had before seen among the varieties of the tame Duck. On inquiry, I was informed that, three years before, a pair of these Ducks had been captured in the mill-pond, whether in a trap or by being wounded, I cannot recollect. They were kept in the poultry-yard, and, it was said, were easily tamed. One joint of the wing was taken off to prevent their flying away. In the following spring they were suffered to go into the pond, and they returned daily to the house to be fed. They built a nest on the edge of the pond, and reared a large brood. The young were perfectly reconciled to domestication, and made no attempts, even at the migratory season, to fly away, although their wings were perfect. In the following season they produced large broods. The family of the miller used them occasionally as food, and considered them equal in flavour to the Common Duck, and more easily raised."-Aud. Orn. Biogr., vol. v. p. 354.

To say there is no external difference in the sexes would be to assert an untruth; but, the male being much less adorned than the males of its congeners, the sexes are necessarily much more alike. The female is in fact very similarly clothed to the female of the common Wild Duck (Anas boschas), but may at all times be distinguished from her mate by her plainer clothing and by the greater delicacy of her structure.

The male has the head and neck greyish brown, spotted and ringed on the nape with dark brown; the under part of the neck, back, and breast lunulated with black; scapularies and sides barred with zigzag lines of white and brownish black; lesser wing-coverts chestnut-red; greater coverts, rump, and under tail-coverts black; speculum pure white, bordered below with black, so as to form three broad bands on the wing of chestnut, black, and white; abdomen dull white; rump and tail-coverts glossed with green ; bill blackish olive; irides hazel; legs, toes, and interdigital membranes orange-yellow, claws black.

The female has the head mottled brown, streaked with blackish brown; a pale stripe over the eye; upper and under surface light reddish brown, each feather edged with a lunule of blackish brown in the centre, lesser wing-coverts hair-brown, with paler margins; speculum the same as in the male; tail dark brown, edged and tipped with buffy brown and white; chin and throat white; abdomen white; bill paler than in the male, and margined with yellowish orange.

The Plate represents a male of the size of life, and a female considerably reduced. 


\section{$2 \mathrm{BHL}$ Biodiversity Heritage Library}

Gould, John. 1873. "Gadwall, Chaulelasmus strepera [PI. 19]." The birds of Great Britain 5, -. https://doi.org/10.5962/p.324063.

View This Item Online: https://www.biodiversitylibrary.org/item/222497

DOI: https://doi.org/10.5962/p.324063

Permalink: https://www.biodiversitylibrary.org/partpdf/324063

\section{Holding Institution}

Smithsonian Libraries

\section{Sponsored by}

Biodiversity Heritage Library

\section{Copyright \& Reuse}

Copyright Status: Public domain. The BHL considers that this work is no longer under copyright protection.

This document was created from content at the Biodiversity Heritage Library, the world's largest open access digital library for biodiversity literature and archives. Visit BHL at https://www.biodiversitylibrary.org. 